\title{
Peran Organisasi Masyarakat Sipil dalam Proses Perintisan Sistem Informasi Desa di Kalibening Dukun Magelang Jawa Tengah The Role of Civil Society Organizations in Pioneering Village Information System in Kalibening, Dukun, Magelang, Central Java
}

\section{Anggalih Bayu Muh. Kamim}

Fakultas Ilmu Sosial dan Ilmu Politik, Universitas Gadjah Mada

email: anggalih.bayu@yahoo.co.id

\section{Riwayat Artikel}

Diterima 31 Juli 2019

Direvisi 25 September 2019

Disetujui 7 Oktober 2019

doi: https://doi.org/10.22212/ jp.v10i1.1346

\begin{abstract}
Balai Sakinah 'Aisyiyah community group has an important role as the development partner of the Kalibening Village, Dukun District, Magelang Regency. The MAMPU financial assistance scheme has encouraged BSA to drive innovation in pioneering the village information system (SID) in Kalibening. The pioneering of the said village information system was carried out in collaboration with students, the village government and some residents. An assessment of the village information system development process in Kalibening must be carried out to evaluate the overly dominant role of technical assistance in village development. This research was conducted with a participatory research method to allow researchers be a part of the studied phenomenon to explore the paradoxes that emerged from implementing the Balai Sakinah Aisyiyah's technical assistance in pioneering the village information system in Kalibening, Dukun, Magelang. The data collection and analysis were carried out throughout the development of the village information system during the Gadjah Mada University community engagement program in Kalibening Village for a period of 50 days. The results of the study show that the model of technical assistance advocated by BSA in pioneering SID does indeed help the village innovation process. However, paradoxes arise in the disproportionately bigger role that civil society organizations played compared to that of the villagers. Civil society organizations designed the SID development method without prior consultations with the villagers. The dominance of the civil society organizations also resulted in knowledge gaps among villagers. They become nothing more than merely an object for data collection. Nevertheless, the students involved in the community engagement program facilitated the villagers to utilize the resulting data.
\end{abstract}

Keywords: Technical Assistance; Civil Society Organization; the Village Information System.

\begin{abstract}
Abstrak
Balai Sakinah 'Aisyiyah (BSA) memiliki peranan penting sebagai mitra pembangunan desa Kalibening, Kecamatan Dukun, Kabupaten Magelang. Bantuan skema donor MAMPU mendorong keterlibatan BSA dalam mendorong inovasi perintisan sistem informasi desa di Kalibening. Perintisan sistem informasi desa dilakukan bersama dengan para mahasiswa, pemerintah desa dan sebagian warga. Pengkajian terhadap proses perintisan sistem informasi desa di Kalibening perlu didalami untuk mengevaluasi terlalu dominannya peran bantuan teknis dalam pembangunan desa. Penelitian ini dilakukan dengan metode penelitian partisipatif untuk menjadikan peneliti menjadi bagian dari fenomena yang dikaji untuk menggali paradoks yang muncul dari pelaksanaan bantuan teknis BSA dalam perintisan sistem informasi desa di Kalibening, Dukun, Magelang. Pengumpulan dan analisis data dilakukan sepanjang pelaksanaan program perintisan sistem informasi di desa selama pelaksanaan KKN PPM UGM di Desa Kalibening selama 50 hari. Hasil penelitian menunjukan bahwa model bantuan teknis yang didorong BSA dalam perintisan SID memang membantu proses inovasi desa. Akan tetapi, muncul berbagai paradoks dalam peran organisasi masyarakat sipil yang terlalu banyak dibandingkan peran warga. Organisasi masyarakat sipil menentukan sendiri metode yang dipakai dalam perintisan SID tanpa terlebih dahulu melibatkan warga lain. Dominasi peran organisasi masyarakat sipil juga membawa masalah kesenjangan pengetahuan dengan warga. Warga semata menjadi objek yang kemudian coba dimediasi oleh mahasiswa KKN untuk dapat memanfaatkan data. Penelitian ini merekomendasikan kepada para pemangku kepentingan di Kalibening untuk melibatkan kelompok sasaran lain seperti kelompok tani, PKK, dan lain-lain dalam pemanfaatan sistem informasi desa. Kata Kunci: Bantuan Teknis; Organisasi Masyarakat Sipil; Sistem Informasi Desa.
\end{abstract}




\section{Pendahuluan}

Kajian ini akan mendalami terkait upaya inisiasi sistem informasi desa (SID) oleh pemerintah Desa Kalibening, Kecamatan Dukun, Kabupaten Magelang bekerjasama dengan kader organisasi 'Aisyiyah dan sebagian warga. Pendalaman terhadap upaya menjadikan SID sebagai basis data pembangunan penting untuk dilakukan untuk memastikan bahwa upaya "kodifikasi" potensi desa dan pengetahuan lokal bukan semata menjadi alat teknokrasi. Pendalaman terhadap SID yang semata hanya menjadi sumber daya baru bagi pemerintah desa dan memunculkan ketimpangan pada pemahaman anggota masyarakat hanya akan memunculkan problem baru dalam upaya mendorong tata kelola berbasis komunitas.

SID digunakan dalam dua bentuk, yakni sebagai inventarisasi potensi desa dan sumber informasi pelayanan publik. ${ }^{1}$ Proses otomatisasi data potensi desa perlu dilakukan untuk menunjang efisiensi dan efektivitas pemerintahan desa. Database terpadu disusun oleh pemerintah desa untuk memastikan proses pembukuan dan inventaris desa dapat berjalan dengan lancar. ${ }^{2}$ Database terpadu SID diperlukan untuk memberikan informasi pada seluruh anggota masyarakat desa mengenai potensi, kelembagaan, fasilitas publik, prioritas pembangunan, monografi dan lain-lain. SID menjadi wujud transparansi dari pemerintah desa untuk mendorong warga

1 Syarif Hidayatulloh and Cisde Mulyadi, "Sistem Pelayanan Administrasi Kependudukan Desa Candigatak Berbasis Web," Jurnal IT CIDA 1, No. 1 (2015): 42-55; Herpendi, "Sistem Informasi Desa Di Kecamatan Takisung," Jurnal Sains Dan Informatika 3, No. 2 (2017): 76-82; Paryanta, Sutariyani, and Desi Susilowati, "Sistem Informasi Administrasi Kependudukan Berbasis Web Desa Sawahan," IJSE - Indonesian Journal on Software Engineering 3, No. 2 (2017): 77-81.

2 Fitrah Rumaisa and Robby, "Perancangan Sistem Informasi Aplikasi Untuk Pemerintahan Tingkat Desa Di Desa Dan Kelurahan,” researchgate, 2010, https:// www.researchgate.net/publication/303881416 Perancangan_Sistem_Informasi_Aplikasi_untuk_ Pemerintahan_tingkat_desa_di_Desa_dan_Kelurahan. ikut berpartisipasi dalam pembangunan desa. ${ }^{3}$ Sayangnya, kajian-kajian ini tidak menjelaskan efektivitas partisipasi warga yang muncul sebagai dampak dari adanya penyampaian informasi desa melalui SID.

Berdasarkan penelitian lain ditemukan bahwa SID sebenarnya hanya dibutuhkan sebagai bagian dari administrasi publik dibandingkan bahan partisipasi warga. Penelitian ini menemukan bahwa Badan Perencanaan Pembangunan Daerah (Bappeda) membutuhkan SID untuk melakukan sinkronisasi penggunaan ruang. Bappeda juga berpandangan bahwa penggunaan SID akan membantu pelaksanaan pembangunan desa yang akan disesuaikan dengan prioritas pembangunan daerah dan nasional. Bagi pemerintah desa yang diteliti berpandangan bahwa SID penting digunakan sebagai fondasi inventarisasi pembangunan sekaligus memetakan sumber daya. Warga desa dinilai kurang begitu terpengaruh dengan keberadaan SID. ${ }^{4}$

Pengembangan SID juga tak lepas sebagai bagian dari mekanisme top down yang didorong pemerintah desa dalam perencanaan dan pelaksanaan pembangunan. Berdasarkan studi lain terhadap Gerakan Desa Membangun (GDM) menemukan bahwa pembangunan pedesaan berbasis internet sangat bergantung pada mekanisme administrasi publik, dibandingkan partisipasi warga. Pengembangan SID yang diinisiasi pemerintah dengan supra desa pada dasarnya meningkatkan ketergantungan desa pada pihak luar. ${ }^{5}$

3 Mansur and Kasmawi, "Pengembangan Sistem Database Terpadu Berbasis Web Untuk Penyediaan Layanan Informasi Website Desa," Teknosi 3, No. 1 (2017): 73-82.

4 Desi Syafriani, "Purwarupa Sistem Informasi Geografis Bebrasis Web Untuk Pemerintah Desa (Studi Kasus Desa Karangsari Kabupaten Kulon Progo)," Momentum 19, No. 2 (2017): 41-49.

5 Muhammad Badri, "Pembangunan Pedesaan Berbasis Teknologi Informasi Dan Komunikasi (Studi Pada Gerakan Desa Membangun),” Risalah 27, No. 2 (2016): $62-73$ 
Kajian lain ada yang melihat bahwa pembuatan SID menjadi pelaksanaan dari government to citizen. Pola ini mengklaim bahwa pemerintah desa menjadi abdi negara yang perlu memanfaatkan teknologi untuk melakukan pelayanan publik. Hal ini tentu bermasalah disebabkan kembali mengakomodasi mekanisme top down di tengah semangat menunjang otonomi desa. Pemerintah desa hanya dipandang sebagai street level bureaucracy dari pelayanan publik yang dilakukan oleh negara. Dengan demikian, posisi negara justru semakin diperkuat sebagai pihak yang mengerti mengenai pembangunan, sedangkan warga hanya sekadar diberikan tampilan informasi mengenai kebijakan yang akan mereka ambil. ${ }^{6}$

Pemerintah desa sendiri masih bergantung pada pihak developer web SID dalam penggunaannya. Pihak developer masih perlu melakukan berbagai pelatihan dan pendampingan dalam perintisan SID, sehingga pemerintah desa mulai lihai dalam penggunaan website. ${ }^{7}$ Pihak developer juga masih perlu menyusun modul penggunaan website SID sebelum menggunakannya. ${ }^{8}$ Aparat desa sebenarnya kurang memiliki kepedulian mengenai arti penting pemetaan wilayah dalam perintisan SID. Pihak developer SID pada dasarnya akan memberikan penyuluhan dan pendampingan, agar pemerintah desa memiliki awareness terhadap pembuatan SID. Kajian ini juga menemukan bahwa kebergantungan pada developer menyebabkan implementasi SID belum tentu berjalan lancar. ${ }^{9}$

6 Suranto, "Evaluasi Program Desa Mandiri Informasi Berbasis Aplikasi Android Sistem Informasi Desa (SIFORDES)," INFORMASI: Kajian Ilmu Komunikasi 48, No. 1 (2018): 1-13.

7 Apriyansyah, Isnaini Maullidina, and Eko Priyo Purnomo, "Efektivitas Sistem Informasi Desa (SID) Dalam Pelayanan Publik Di Desa Dlingo, Kecamatan Dlingo, Kabupaten Bantul," Jurnal Analisis Kebijakan Dan Pelayanan Publik 4, No. 1 (2018): 10-24.

8 Iqbal Firdaus and Riyanto, "Perancangan Website Pemerintah Desa Sebagai Media Penyebaran Informasi Bagi Masyarakat Dengan Metode Waterfall," Jurnal SAINSTECH Politeknik Indonusa 2, No. 6 (2016): 3440.

9 Bambang Sudarsono And Arief Laila Nugraha, "Kajian
SID tampaknya lebih terlihat sebagai proyek antara developer dan pemerintah desa dibandingkan menjadi milik komunitas. Pihak developer sengaja membawa proyek SID sebagai bagian dari bentuk intervensinya terhadap pemerintah desa tanpa melihat urgensi dan sumber daya pendukung. Pada dasarnya sebagian besar aparat desa sendiri kurang terampil dalam menggunakan perangkat teknologi informasi. Aparat desa sendiri pada dasarnya masih kesulitan dalam mendokumentasikan inventaris dan sumber daya yang dimiliki. Selain itu, minimnya ketersediaan fasilitas penunjang berupa sarana komputer yang memadai memperlihatkan bahwa SID sebenarnya belum menjadi fokus pemerintah desa dalam pembangunan. ${ }^{10}$

Pola yang berbeda muncul dengan hadirnya sumber informasi desa yang diinisiasi oleh masyarakat. Proses pembentukan "SID" berbasis komunitas melalui radio muncul pasca gempa DIY Tahun 2006, di mana muncul masalah kesulitan manajemen data kependudukan. Inisiasi "SID" dilakukan warga dengan mensosialisasikan radio komunitas pada warga. Radio komunitas ini kemudian mendorong adanya pengembangan inventarisasi potensi dan sumber daya desa berbasis website. Berbeda dengan SID berbasis website yang didorong oleh developer yang masuk ke desa pada umumnya yang tanpa ditopang oleh proses tata kelola komunitas, sehingga sekadar penyampaian informasi satu arah. ${ }^{11}$

Perintisan sistem informasi desa dari dorongan masyarakat sipil juga muncul di Kalibening, Dukun, Magelang, Jawa Tengah. Jejaring organisasi masyarakat sipil yang sudah

Pendampingan Aparat Desa Dalam Kemandirian Pemetaan Infrastruktur Dan Potensi Desa (Studi Kasus: Desa Katonsari, Kabupaten Demak)," Elipsoida 1, No. 1 (2018): 39-46.

10 Yoseph Pius Kurniawan Kelen and Oktovianus Sikas, "Workshop Sistem Informasi Desa Dan Kawasan (SiDeKa) Desa Fatuana, Kecamatan Insana," Jati Emas (Jurnal Aplikasi Teknik Dan Pengabdian Masyarakat) 2, No. 2 (2018): 50-57.

11 Fadjarini Sulistyowati and MC. Candra Rusmala Dibyorin, "Partisipasi Warga Terhadap Sistem Informasi Desa," Jurnal Komunikasi ASPIKOM 2, No. 1 (2013): 579-87. 
kuat yakni, Balai Sakinah 'Aisyiyah (BSA) mendorong pemerintah desa Kalibening untuk melakukan pembuatan sistem informasi desa. Sebelumnya BSA telah membantu pemerintah desa dalam membuat inovasi kebijakan berupa peraturan pemerintah desa tentang kesehatan reproduksi. Perintisan sistem informasi desa yang didorong oleh BSA dilakukan untuk memberikan basis data bagi pelayanan dan pelaksanaan kebijakan reproduksi sekaligus inventarisasi pembangunan. Proyek perintisan SID oleh BSA ini kemudian juga dibantu oleh tim KKN PPM UGM JT-133 dalam pelaksanaannya. Studi terhadap perintisan SID di Kalibening menjadi menarik untuk digali untuk melihat paradoks yang mungkin muncul akibat inisiasi SID yang diusung oleh organisasi masyarakat sipil dan dibantu tim KKN PPM UGM JT-133. Dominasi terhadap peran organisasi masyarakat sipil dalam perintisan SID perlu dievaluasi, agar warga dan pemerintah desa tidak semata menjadi objek pelaksanaan bantuan teknis dari BSA.

\section{Kerangka Teori}

Kajian ini akan dibingkai dengan pemahaman mengenai metode pemberdayaan technical assistance (TA) untuk memahami keterlibatan BSA, tim KKN PPM UGM JT133 dan pemerintah Desa Kalibening dalam perintisan Sistem Informasi Desa. Technical assistance sendiri menurut Trohanis (1980) dapat dimaknai sebagai pendampingan dari pihak luar institusi untuk meningkatkan kapasitas manajemen, organisasi dan informasi anggota komunitas melalui berbagai program yang telah dirancang dengan bentuk berbagai layanan. Technical assistance melibatkan para perencana program dan trainer yang akan menyusun kerangka kerja operasional untuk memfasilitasi peningkatan kapasitas kliennya untuk mencapai target perubahan tertentu. ${ }^{12}$

12 Pascal Louis Trohanis, "Technical Assistance: An Innovative Approach to Building New Partnerships in Continuing and Inservice Education," Educational Technology 20, No. 8 (1980): 30-36.
Pelaksana TA biasanya dapat berbentuk perguruan tinggi, lembaga konsultan ataupun organisasi masyarakat sipil yang memiliki kelebihan pada bidang tertentu, sehingga menawarkan berbagai program pada calon kliennya. Pelaksana TA terkadang juga menjadi bagian dari pelaksanaan hibah pendanaan pembangunan tertentu yang perlu dikerjakan pada kelompok sasaran yang dituju. Mereka akan memanfaatkan seperangkat pemahaman teoretisnya untuk diwujudkan ke dalam berbagai program pendampingan untuk meningkatkan kapasitas kliennya. Pelaksana TA biasanya akan menentukan kelompok sasaran yang perlu diberikan intervensi tertentu untuk mencapai perubahan yang diinginkan. Pelaksana TA akan menyediakan berbagai intervensi baik dalam bentuk pelatihan, magang, studi banding, dan lainlain untuk mendorong peningkatan kapasitas kelompok sasaran. Kelompok sasaran akan didorong untuk menyesuaikan diri untuk mencapai target kerja dari program yang telah dirancang oleh si pendamping. ${ }^{13}$

Pelaksana TA tidak menggunakan pendekatan tunggal, tetapi mengadaptasi pekerjaan mereka berdasarkan jenis kebutuhan, pencapaian perubahan yang diharapkan, tujuan yang ditentukan, dan pengalaman sebelumnya dengan kelompok sasaran, serta gaya pribadi mereka, pengalaman bertahun-tahun, keahlian, dan tingkat kepercayaan. Hal ini membuat tujuan pelaksanaan TA beragam, mulai dari tingkat mikro, seperti menyediakan sumber daya hingga tingkat makro, seperti membantu mencapai perubahan yang diharapkan kelompok sasaran yang telah ditentukan sebelumnya secara taktis serta terkait langsung dengan kepentingan komunitas/institusi. Metode yang akan dipilih pun sangat dinamis dengan memanfaatkan pendekatan yang

13 William B. Storm and Frank P. Sherwood, "Technical Assistance in Public Administration: The Domestic Role," Public Administration Review 14, No. 1 (1954): $32-39$. 
lebih strategis dan fokus pada perencanaan, mengartikulasikan gambaran besar, mengenali pola dan tren, dan mengantisipasi munculnya masalah baru. Hasil pelaksanaan TA terkadang lebih bersifat individual, lalu dikembangkan dan diimplementasikan bersama, dan diadaptasi sesuai dengan umpan balik penerima dan evaluasi. ${ }^{14}$

Pelaksana terkadang merasa cakupan TA bergeser dari program pemberdayaan dengan tujuan konkret dengan fokus pada bidang tertentu. Akan tetapi, seiring meningkatnya kebutuhan dan jumlah kelompok sasaran, program yang dilaksanakan juga menyesuaikan. Tantangan pada substansi program muncul pada hal yang bersifat teknis, sedangkan terkait dengan hubungan yang terjalin antara pelaksana dan kelompok sasaran bergantung pada penyesuaian yang dilakukan dalam membangun prioritas kebutuhan. Institusi/ komunitas akan menghadapi tantangan teknis berupa penyelarasan paradigma, nilai dan prosedur untuk memfasilitasi pelaksanaan program. Transfer informasi di antara kedua belah pihak menjadi sangat penting dalam pelaksanaan program. ${ }^{15}$

Ada beberapa karakteristik yang mempengaruhi pelaksanaan transfer informasi dalam pelaksanaan TA, yakni: (1) TA yang diberikan dalam situasi apa pun adalah hampir selalu merupakan campuran pendekatan substansi program dan hubungan antar aktor; (2) tidak ada nilai yang dominan; dan (3) penyesuaian terhadap kedua pendekatan untuk setiap situasi menjadi kunci keberhasilan. Sementara, pendamping melakukan transfer informasi yang bergantung pada perilaku dan perubahan sistem. Pendekatan berbasis hubungan antar aktor kuat dianggap perlu untuk memahami faktor internal yang berpengaruh dalam pelaksanaan program,

14 Lan T. Le et al., "A Technical Assistance Model for Guiding Service and Systems Change," The Journal of Behavioral Health Services $\mathcal{E}$ Research, 2014, 1-15.

15 Le, "Technical Assistance". seperti karakteristik kelompok penerima, tujuan dan budaya yang diidentifikasi, sikap, kepercayaan, dan persepsi. Pelaksanaan TA juga dipengaruhi oleh keahlian, pengalaman kelompok sasaran, dan kondisi organisasi yang mencakup jabatan, tingkat pengaruh, dan kemampuan untuk menyelesaikan masalah. Motivasi dan kesiapan kelompok juga diidentifikasi sebagai faktor kontekstual yang penting. ${ }^{16}$

TA dapat membangun sinergi yang kuat di antara personel institusi dan organisasi pendamping dengan menumbuhkan rasa saling percaya. Pelaksanaan program dalam skema TA dapat membantu mengatasi berbagai permasalahan yang dihadapi institusi/ komunitas seperti perlunya peningkatan kapasitas sumber daya manusia, menyiapkan daya adaptif menghadapi tantangan perubahan sosial, dan menyiapkan berbagai elemen anggota untuk mencapai keadaan yang lebih baik. Pelaksanaan TA setidaknya dilaksanakan melalui tiga skema. Pertama, pelaksanaan program untuk mencapai perubahan organisasi. Pada skema ini, ada upaya dari pendamping untuk berkolaborasi dengan mitranya mencoba menerapkan pengetahuan dalam identifikasi permasalahan kelompok. Kemudian, proses selanjutnya akan dilaksanakan perancangan dan pelaksanaan program. Pelaksanaan skema ini sangat bergantung pada usaha saling menentukan tujuan di antara pendamping dan klien yang disokong oleh kekuatan bersama, komunikasi, rasa saling percaya dan pelibatan kontribusi pihak luar dalam pencapaian program. ${ }^{17}$

Kedua, upaya melalui difusi sosial dan inovasi dalam pemberdayaan. Skema ini membantu kelompok sasaran untuk mendefinisikan kebutuhan, mendiagnosis masalah, memperoleh sumber daya, memilih atau membuat solusi, beradaptasi dan memastikan program yang dirancang apakah

16 Le, "Technical Assistance".

17 Trohanis, "Technical Assistance". 
akan memuaskan kebutuhan klien. Pemetaan masalah dan sumber daya yang dimiliki ini juga akan membantu kelompok sasaran dan pendamping untuk memastikan seberapa besar daya dukung resources dalam mencukupi kebutuhan. ${ }^{18}$

Ketiga, skema yang melibatkan kelompok sasaran dalam keseluruhan pelaksanaan program baik perancangan sampai pelaksanaan monitoring dan evaluasi. Skema ini dilakukan melalui penciptaan iklim yang kondusif selama pelaksanaan berlangsung, perencanaan bersama-sama, mendiagnosis kebutuhan, membentuk kepercayaan dan rasa saling memiliki untuk menyelesaikan program dari awal hingga akhir. Skema ini mendorong adanya kontrak bersama antara pendamping dengan kelompok sasaran untuk memastikan bahwa layanan yang diberikan dalam program pemberdayaan terlaksana sesuai dengan target yang ditentukan. Meskipun, pendamping tetap menjadi pihak yang paling mengerti mengenai manajemen program, kelompok sasaran harus mendapatkan penguasaan informasi yang sama. Hal tersebut dilakukan untuk memastikan target yang ditentukan benar-benar tercapai. ${ }^{19}$

Kajian ini akan dibingkai dengan model difusi dan inovasi sosial yang dilakukan oleh BSA dan dibantu oleh tim KKN PPM UGM JT133 dalam memahami proses perintisan SID di Desa Kalibening. Proses perintisan SID yang dilakukan dengan seluruh tahapan penentuan target perubahan yang ingin dicapai dalam pemberdayaan sampai monitoring \& evaluasi yang dimotori oleh BSA akan menunjukan bagaimana proses inovasi sosial dimotori oleh organisasi masyarakat sipil melalui bantuan teknis. Model difusi dan inovasi sosial akan membantu menjelaskan bagaimana proses kelompok sasaran yang juga dilibatkan oleh organisasi masyarakat sipil dalam perancangan sampai evaluasi program perintisan SID di

18 Trohanis, "Technical Assistance".

19 Trohanis, "Technical Assistance".
Desa Kalibening, Dukun, Magelang. Proses pembuatan SID yang didorong oleh BSA akan dipahami sebagai proses difusi dan inovasi sosial yang dilakukan melalui bantuan teknis di Desa Kalibening itu sendiri.

Model difusi dan inovasi sosial dalam TA juga akan membantu menjelaskan proses meleburnya tim KKN PPM UGM JT-133 dengan organisasi 'Aisyiyah dalam proses perintisan SID di Desa Kalibening. Model ini juga akan membantu proses keterlibatan penulis dalam tim KKN JT-133 UGM dalam perintisan SID bersama dengan kader 'Aisyiyah, pemerintah Desa Kalibening dan sebagian warga. Model ini akan membantu menerjemahkan dinamika program pemberdayaan yang diusung oleh 'Aisyiyah dengan seperangkat metode pendampingannya. Perintisan SID juga menjadi bagian dari inovasi kebijakan sebelumnya yang dibawa oleh kader 'Aisyiyah. Pembacaan terhadap proses intervensi organisasi 'Aisyiyah untuk mencapai target perubahan yang ingin dicapai pemerintah Desa Kalibening dan dibantu tim KKN PPM UGM JT-133 akan memberikan evaluasi tentang bagaimana intervensi supra desa di satu sisi mendorong terjadinya inovasi sosial, tetapi juga berakibat pada partisipasi yang hanya dinikmati segelintir orang.

\section{Metode Penelitian}

Kajian ini adalah penelitian partisipatif dilakukan di Desa Kalibening, Kecamatan Dukun, Kabupaten Magelang selama 50 hari dalam rentang Desember tahun 2018 hingga Februari 2019. Peneliti terlibat langsung dalam proses perubahan organisasi yang ingin dicapai subjek penelitian dengan sebelumnya membangun kesepakatan bersama. ${ }^{20}$ Pengumpulan data dilakukan mulai dari awal sampai berakhirnya kegiatan KKN PPM UGM JT-133 di Desa Kalibening. Peneliti khususnya

20 William F. Whyte, "Advancing Scientific Knowledge Through Participatory Action Research," Sociological Forum 4, No. 3 (1989): 367-85. 
mendalami terkait dengan peran BSA sebagai organisasi masyarakat sipil dalam proses perintisan SID yang dibuat semenjak bulan Oktober tahun 2018 s.d. Februari tahun 2019. Analisis data dilakukan mulai dari penjajakan kegiatan tim KKN PPM UGM JT-133 untuk terlibat dalam proses perintisan SID dengan BSA, pelaksanaan program sampai dengan masa berakhirnya periode KKN PPM UGM pada bulan Februari Tahun 2019.

Peneliti menggunakan lima jenis validitas yang disesuaikan dengan asumsi dan tujuan yang mendasarinya, yakni validitas hasil, validitas demokratis, validitas proses, validitas katalistik, dan validitas dialogis. Validitas hasil maksudnya adalah penelitian harus mengarah pada penyelesaian masalah yang relevan dengan sukses. Validitas demokratis adalah sejauh mana kepentingan yang relevan antar subjek penelitian dalam berpartisipasi secara mendalam dalam penyelesaian masalah dan sejauh mana perspektif dan kebutuhan mereka diakomodasi dalam proses penelitian. Validitas proses adalah sejauh mana masalah diselidiki dengan cara yang memungkinkan untuk pembelajaran dan peningkatan berkelanjutan. Validitas proses akan dipengaruhi oleh kualitas hubungan antar peneliti dan subjek penelitian. Seperti dalam penelitian interpretatif, kepercayaan dan hubungan penting untuk menghasilkan data yang berkualitas. Validitas katalistik adalah sejauh mana penelitian mampu untuk memahami dan mengubah realitas sosial baik di dalam maupun di luar proses penelitian. Validitas dialogis mengacu pada dialog kritis dengan subjek penelitian mengenai temuan dan tindakan penelitian. Validitas dialogis mensyaratkan peneliti terlibat dalam perdebatan untuk mencari temuan penjelasan alternatif, asumsi bermasalah, bias dan kegagalan untuk memasukkan pemangku kepentingan kunci, dan sebagainya. ${ }^{21}$

21 Kevin Burke and Stuart Greene, "Participatory Action Research, Youth Voices, and Civic Engagement," Language Arts 92, No. 6 (2015): 387-400.

\section{Keterlibatan Balai Sakinah 'Aisyiyah dalam Pembangunan Desa Kalibening}

Desa Kalibening terdiri atas sembilan dusun yakni, Argosono, Cepek, Ngentak, Gintung, Gendungan, Kalibening Kulon, Kalibening Wetan, Demo dan Windusari. Tiap dusun menghasilkan formasi sosial yang berbeda terkait dengan organisasi masyarakat Nahdlatul Ulama dan Muhammadiyah. Pemahaman terhadap formasi sosial ini menjadi penting untuk memahami program pemberdayaan yang dilakukan pemerintah Desa Kalibening dengan bantuan kader-kader organisasi masyarakat tersebut.

Dusun-dusun yang berada di sebelah utara, yakni Windusari, Kalibening Kulon, Kalibening Wetan, Gintung, dan Demo memiliki ikatan kuat dengan organisasi ranting Muhammadiyah. Formasi sosial yang ada di dusun-dusun ini mempengaruhi kegiatan organisasi masyarakat yang ikut diterapkan pada warga. Organisasi di bawah naungan Muhammadiyah yang memiliki peran kuat dalam aktivitas warga di dusun-dusun tersebut adalah Balai Sakinah 'Aisyiyah (BSA) yang mendorong aktivitas perempuan tidak hanya pada PKK (Pembinaan Kesejahteraan Keluarga). Mereka yang tergabung dalam Balai Sakinah 'Aisyiyah tidak semua perempuan yang ada di dusun, tetapi warga yang menjadi bagian dari Persyarikatan Muhammadiyah.

Dusun Ngentak, Cepek, Gendungan dan Argosono memiliki ikatan kuat dengan organisasi Nahdlatul Ulama. Aktivitas warga yang memiliki ikatan kuat dengan NU ini lebih banyak pada kegiatan kultural seperti pengajian, tahlilan, hadroh, dan lain-lain. Di dusun-dusun ini juga terdapat beberapa perempuannya yang menjadi bagian dari kader BSA. Kader-kader BSAdidusun-dusun tersebut aktif dalam menyelenggarakan pelatihan pengolahan pangan untuk meningkatkan perekonomian keluarga. Meskipun tiap dusun memiliki formasi sosial yang berbeda, pada 
dasarnya di antara keseluruhan warga, kaderkader BSA inilah yang menjadi mitra penting pemerintah desa dalam pembangunan. Kaderkader BSA di dusun Kalibening memang memainkan peranan penting dalam proses pemberdayaan dengan adanya dorongan program dari Pimpinan Pusat (PP) 'Aisyiyah di Yogyakarta. Upaya pelibatan partisipasi khususnya perempuan melalui BSA ini memang sengaja dijadikan role model dengan adanya bantuan dari lembaga donor.

BSA memiliki kontribusi besar dalam pembangunan di Desa Kalibening dengan mendapat bantuan donor dari program MAMPU (Maju Perempuan Indonesia Untuk Penanggulangan Kemiskinan) dari Australia. Australia menjalin kerjasama dan membentuk program MAMPU dilatarbelakangi oleh usaha membuat berbagai kerjasama salah satunya ialah kesetaraan gender dan pemberdayaan dalam meningkatkan pertumbuhan ekonomi bagi perempuan Indonesia. ${ }^{22}$

Program yang dilaksanakan BSA di Desa Kalibening sendiri menjadi bagian dari skema Fase II Program MAMPU. Fase II muncul setelah adanya penandatanganan subsidiary arrangement antara Badan Perencanaan Pembangunan Nasional (Bappenas) tentang Kemitraan Australia-Indonesia untuk Kesetaraan Gender dan Pemberdayaan Perempuan pada tahun 2017. ${ }^{23}$ BSA menjadi mitra dalam Program MAMPU khususnya dalam isu kesehatan reproduksi. MAMPU memperkuat kerja 'Aisyiyah yang telah lama berlangsung bersama Pusat Kesehatan Masyarakat (Puskesmas) dengan mendukung mereka dalam membentuk kelompok perempuan berbasis desa yang disebut Balai

22 Julita Silaban, "Kemitraan Indonesia-Australia Melalui Program Mampu (Maju Perempuan Indonesia Untuk Penangulangan Kemiskinan) Untuk Pemberdayaan Perempuan," Repository Unikom, 2017, https:// repository.unikom.ac.id/54461/.

23 Sri Ok Suryani, "Motivasi Indonesia Menandatangani Subsidiary Arrangement Program Mampu Fase II Dengan Australia TAHUN 2017," JOM FISIP 5, No. 1 (2018): 1-14.
Sakinah 'Aisyiyah (BSA). Melalui BSA, 'Aisyiyah telah mengembangkan layanan yang mencakup penguatan kesadaran perempuan akan kanker serviks dan kanker payudara, dan pada saat yang sama mendukung Puskesmas untuk meningkatkan responsivitas. Anggota BSA membantu pemerintah daerah mengembangkan 'sistem umpan balik' untuk memastikan pusat kesehatan memenuhi Standar Pelayanan Minimal (SPM) mereka. ${ }^{24}$

Skema donor telah membantu BSA mendorong inovasi kebijakan di Desa Kalibening. BSA membantu terbentuknya Peraturan Desa (Perdes) Kalibening tentang Pemenuhan Hak Kesehatan Reproduksi dan Gizi. Pada 2016, hak kesehatan reproduksi belum menjadi pemahaman yang umum bagi pemerintah dan masyarakat Desa Kalibening. Lalu, BSA di Desa Kalibening melakukan pengarusutamaan isu kesehatan reproduksi melalui program pendampingan kelompok. Secara perlahan, pemerintah dan masyarakat Desa Kalibening mulai menaruh perhatian pada isu tersebut. ${ }^{25}$

BSA juga mengajarkan para perempuan untuk berani memberikan usulan dan menyampaikan kebutuhan mereka melalui forum yang tersedia di desa yakni Musrenbangdes. Ada harapan BSA akan semakin mendorong munculnya banyak kebijakan-kebijakan yang berpihak kepada perempuan yang dilakukan oleh pemerintahan Desa Kalibening juga pemerintahan desa yang lainnya. ${ }^{26}$ Hubungan baik antara organisasi masyarakat sipil dan aparat desa ini dapat 24 Bappenas and Australian Government, "M A M P U 2012 - 2020 Kemitraan Australia-Indonesia Untuk Kesetaraan Gender Dan Pemberdayaan Perempuan,” mampu.or.id, 2019, http://www.mampu.or.id/wpcontent/uploads/2019/02/181008_Mampu-InfokitID_FIN-lowerres.pdf.

25 Anonim, "Penggunaan Dana Desa Untuk Program Inovasi Desa," kemendesa.go.id, 2019, https://www. kemendesa.go.id/view/detil/2910/penggunaan-danadesa-untuk-program-inovasi-desa.

26 Anonim, "Mitra MAMPU Berikan Dampak Pada Warga Aisyiyah," Suara Muhammadiyah, 2017, http://www.suaramuhammadiyah.id/2017/07/19/ mitra-mampu-berikan-dampak-pada-warga-aisyiyah/. 
terjadi disebabkan BSA membutuhkan kesempatan dan ruang bagi pelaksanaan program yang telah dibawanya dari skema donor. Pemerintah desa juga senang menjalin hubungan dengan organisasi masyarakat sipil jika agenda yang dimilikinya tidak ditentang dan sejalan dengan program-program yang telah dibawa dari skema donor. ${ }^{27}$

Kader-kader BSA ini selanjutnya semenjak akhir tahun 2018 merintis pembuatan sistem informasi desa untuk menunjang pembangunan. Pelaksanaan perintisan SID ini menjadi perluasan peran BSA di luar isu kesehatan reproduksi dari skema program donor MAMPU. Pengelola donor MAMPU justru membolehkan pemanfaatan skema bantuannya untuk ikut memfasilitasi partisipasi kader BSA dalam pembuatan SID tersebut.

Proses dorongan dari BSA untuk merintis pembuatan SID di Kalibening sendiri dilakukan dengan skema technical assistance untuk mengenalkan pada pemerintah desa mengenai pentingnya pembangunan desa berbasis data. Proses perintisan SID di Desa Kalibening yang dilakukan oleh BSA bersama pemerintah dilakukan dengan tahapantahapan difusi dan inovasi sosial. Pertama, tahapan mempelajari inovasi sistem informasi desa. Tahap ini dimulai kala kader BSA bersama pemerintah desa mulai melihat, dan mengamat inovasi SID dari berbagai sumber. ${ }^{28}$ Pihak BSA bahkan mengadakan lokakarya untuk memberikan sosialisasi pada kader dan pemerintah Desa Kalibening mengenai penggunaan dan proses perintisan SID.

Kedua, adalah tahap pengadopsian, di mana kader BSA dan pemerintah desa yang sudah mendapatkan pemahaman mengenai SID, kemudian memutuskan untuk melakukan

27 John Clark, NGO Dan Pembangunan Demokrasi (Yogyakarta: Tiara Wacana, 1995): 81.

28 Istana dan Zahri Nasuton, "Difusi Peningkatan Kapasitas Kelembagaan Pengelolaan Sumberdaya Perikanan (Studi Kasus Di Waduk Malahayu, Brebes Jawa Tengah)," Buletin Riset Sosek Kelautan dan Perikanan 8, No. 1 (2013): 25-29. proses perintisan basis data. Ada beberapa faktor yang menyebabkan kader BSA mau mengadopsi penggunaan SID dalam pembangunan, yakni pertimbangan terhadap manfaat penggunaan sistem informasi desa, keyakinan terhadap kemampuan trainer yang akan mendampingi mereka dalam proses adopsi, dan rasa percaya dari kader BSA dan pemerintah desa bahwa mereka mampu mewujudkan pembuatan inventarisasi data Kalibening. ${ }^{29}$ Adopsi terhadap penggunaan SID juga disebabkan adanya pertimbangan matang dari pemerintah desa dan kader BSA bahwa penggunaan sistem informasi desa penting untuk memastikan Kalibening dapat menyesuaikan dengan kemajuan teknologi informasi.

Terakhir, adalah tahap pengembangan jaringan sosial. Setelah mengetahui pentingnya perintisan pembuatan SID, pemerintah desa membangun komunikasi dengan Univesitas 'Aisyiyah Yogyakarta untuk membantu menyediakan trainer bagi kader-kader BSA. Pemerintah desa Kalibening juga meminta tim KKN PPM UGM JT-133 yang baru saja datang untuk melakukan kuliah kerja nyata untuk turut membantu dalam kegiatan pembuatan SID. Usaha dari pemerintah desa untuk membangun jejaring sosial ini dilakukan untuk mendorong adanya transfer informasi dan keterampilan, sehingga bisa membantu proses pembuatan SID di Desa Kalibening. ${ }^{30}$ Pemanfaatan jejaring sosial dalam pembuatan SID akan membantu peran BSA dalam menyebarluaskan pemanfaatan teknologi informasi dan komunikasi dalam pembangunan di Desa Kalibening.

Peran pemerintah desa dalam membantu perintisan SID yang dilakukan oleh BSA nampaknya menjadi sangat penting untuk dipahami dalam konteks kesuksesan proses difusi sosial. Pemerintah Desa Kalibening telah menjalankan perannya sebagai opinion leader untuk mendorong pentingnya penerimaan

29 Istana dan Nasuton, "Difusi Peningkatan Kapasitas". 30 Istana dan Nasuton, "Difusi Peningkatan Kapasitas". 
warga atas proyek sistem informasi desa. Pemerintah desa sebagai opinion leader telah menyambut adanya proses inovasi berupa SID untuk mendorong kemajuan masyarakat yang diharapkan dapat memanfaatkan basis data dalam pembangunan. Proses difusi sosial dalam perintisan SID yang difasilitasi pemerintah desa Kalibening berjalan sukses disebabkan opinion leader telah mengembangkan social capital berupa jejaring sosial, rasa saling percaya dan hubungan timbal balik di antara para pemangku kepentingan yang terlibat dalam proses pembuatan sistem informasi desa. ${ }^{31}$

BSA sendiri sebagai pelaksana bantuan teknis pembuatan SID setidaknya melakukan upaya percepatan adopsi dan inovasi sistem informasi desa di Kalibening, Dukun, Magelang dengan beberapa kriteria yang diperhatikan dalam proses difusi sosial. Pertama, BSA memastikan bahwa pemerintah desa dan masyarakat benar-benar membutuhkan SID untuk membantu memecahkan permasalahan yang dihadapi selama ini. Pihak BSA menemukan bahwa pemerintah desa membutuhkan SID disebabkan adanya himbauan dari pemerintah pusat dan pemda untuk segera menyediakan sistem informasi desa bagi basis inventarisasi pembangunan. ${ }^{32}$ Selain itu, tidak adanya basis data yang memadai mengenai seberapa banyak warga yang akan menjadi sasaran kebijakan peraturan desa tentang kesehatan reproduksi yang telah dibuat membuat kehadiran SID menjadi penting. Kedua, BSA memastikan bahwa pembuatan SID akan menguntungkan bagi upaya perbaikan pelayanan masyarakat, khususnya dalam hal kesehatan keluarga. Maka, desain penyajian data yang dibuat

31 Selly Oktarina and Sarwititi Sarwoprasodjo, "Strategi Komunikasi Politik Opinion Leader Dalam Difusi Program Pembangunan Dan Pengembangan Lembaga Lokal Di Pedesaan," MetaCommunication; Journal Of Communication Studies 3, No. 1 (2018): 78-90.

32 Lina Asnamawati, "Strategi Percepatan Adopsi Dan Difusi Inovasi Dalam Pemanfaatan Mesin Tanam Padi Indojarwo Transplanter Di Kabupaten Bengkulu Utara Provinsi Bengkulu," in Prosiding Seminar Nasional FMIPA-UT 2015: Optimalisasi Peran Sains Dan Teknologi Menuju Kemandirian Bangsa, 2015, 1-16. dalam SID pun akan menyesuaikan dengan pelaksanaan pelayanan kesehatan dan program pembangunan lainnya.

Ketiga, BSA memastikan terlebih dahulu bahwa perintisan SID akan sesuai dengan kemampuan sumber daya manusia desa yang akan dilibatkan dalam pembuatan serta penggunaannya. Keempat, BSA juga mendayagunakan sumber daya yang sudah ada dalam pembuatan SID untuk mempercepat proses inovasi. BSA menggerakkan para kadernya yang ada di tiap dusun untuk dilatih dan terlibat dalam pembuatan SID bersama dengan pemerintah desa serta tim KKN PPM UGM JT-133. Terakhir, BSA memastikan bahwa pembuatan SID tidak akan rumit, efisien dan mudah dilakukan oleh pihak-pihak yang terkait dalam pembuatannya. ${ }^{33}$

\section{Perintisan Sistem Informasi Desa dan Sisi Lain "Partisipasi”}

Proses bantuan teknis yang dilakukan oleh BSA dimulai dengan penjajakan program antara pemerintah desa dengan organisasi 'Aisyiyah bersama dengan Universitas 'Aisyiyah Yogyakarta. Keterlibatan BSA dimulai dengan proses identifikasi permasalahan bersama dengan pihak terkait yakni, pemerintah Desa Kalibening dan tokoh masyarakat. BSA dengan pemerintah desa berusaha membangun kesepakatan mengenai pembuatan sistem informasi desa berikut juga dengan kesepakatan timeline kegiatan, agar segera dilaksanakan bersama dengan para pemangku kepentingan. Tahapan awal ini sesuai dengan langkah awal dari metode technical assistance yang mendorong adanya pengambilan keputusan bersama sebagai bentuk perencanaan dan perancangan program.

BSA melakukan proses identifikasi permasalahan dengan bertemu warga, tokoh masyarakat, dan aparat desa yang dimungkinkan dilibatkan dalam pembuatan

33 Asnamawati, "Strategis Percepatan", 1-16. 
sistem informasi desa. BSA bersama pemangku kepentingan mengidentifikasi kebutuhan dan kesiapan dari kelompok sasaran dan organisasi mereka untuk melanjutkan program serta faktor kontekstual untuk memilih pendekatan yang tepat untuk melakukan pembuatan SID. Tim terkadang memaklumkan prioritas permasalahan yang diminta oleh kelompok sasaran untuk diselesaikan. Namun, tim lebih berusaha menciptakan ruang untuk saling belajar dengan kelompok sasaran, di mana mereka mengklarifikasi, mengadaptasi, dan meningkatkan permintaan untuk memberikan dukungan dalam perancangan dan pelaksanaan program. ${ }^{34}$

Tim juga akan mempertimbangkan apakah program yang diminta selaras dengan nilai-nilai organisasi mereka, dengan ruang lingkup kegiatan yang diharapkan oleh penyandang dana (jika berbeda dari kelompok sasaran), dan dengan sumber daya yang tersedia. Tim harus memperhatikan aspek keahlian yang dimiliki anggotanya untuk memastikan apakah sumber daya manusianya memiliki pengetahuan untuk membantu atau membangun hubungan dengan para ahli lainnya atau teman sebaya yang mengerti mengenai proyek dari pemerintah.

Pimpinan Pusat 'Aisyiyah di Yogyakarta kemudian mengirimkan kader-kadernya untuk membantu memberikan pelatihan kepada aparat desa, anggota BSA, dan tokoh masyarakat yang dilibatkan dalam pembuatan sistem informasi desa. Mereka diberikan pelatihan mengenai cara pengambilan data survei dan bagaimana menyajikannya dalam beberapa hari. Pelatihan ini dilakukan untuk menyiapkan para kader sebelum memberikan bantuan teknis pada kelompok sasaran. Pelatihan akan membantu kader pendamping untuk melakukan transfer nilai dan informasi dalam perintisan SID. Pihak Pimpinan Pusat

\footnotetext{
34 Richard P. Francisco, "The Documentation and Technical Assistance Project in Urban Schools," Theory Into Practice 18, No. 2 (1979): 89-96.
}

Aisyiyah berkenan membuat kuesioner yang akan disebar pada warga beserta dengan metode riset yang dipilih. Kader-kader BSA lalu melakukan pengambilan data dengan turun ke tiap dusun pada November Tahun 2018. Pimpinan Pusat 'Aisyiyah juga sebelumnya telah membuat format tabel yang digunakan untuk menyajikan data hasil survei yang dilakukan oleh kader-kader BSA, tokoh masyarakat dan aparat desa.

Kader-kader BSA melanjutkan proses pembuatan sistem informasi desa dengan meng-input satu per satu hasil survei pada tabel yang telah dibuat oleh PP 'Aisyiyah. BSA juga meminta bantuan beberapa mahasiswa dari Universitas Muhammadiyah Magelang untuk membantu menyajikan data hasil survei pada tabulasi yang sudah disediakan. Setelah tim KKN PPM UGM JT-133 datang, BSA juga meminta bantuan mereka untuk membantu menyajikan data hasil survei, agar dapat mengikuti timeline kegiatan yang telah dibuat oleh PP 'Aisyiyah dalam pembuatan SID di Desa Kalibening. Tim KKN PPM UGM JT-133 juga membantu proses input data yang dilakukan oleh mahasiswa Universitas Muhammadiyah Magelang disebabkan mereka ada kegiatan lain yang harus diselesaikan. Tim KKN PPM UGM bersama dengan BSA kemudian menyelesaikan proses input data untuk mengejar deadline tahapan pembuatan SID selanjutnya.

Proses pembuatan sistem informasi desa yang membuat kader-kader BSA, aparat desa dan tokoh masyarakat mampu melakukan proses pengambilan data secara mandiri menunjukan bagaimana bantuan teknis mampu melakukan adopsi inovasi. Tahapan adopsi inovasi dalam bantuan teknis dalam kasus di Kalibening sendiri dapat ditafsirkan melalui beberapa tahapan. Pertama, tahap pengetahuan, di mana kader BSA dan aparat desa mendapat transfer perangkat pengetahuan baru dari para trainer dari PP 
'Aisyiyah, sehingga bisa memiliki keterampilan baru dalam melakukan proses survei untuk yang akan dijadikan basis data SID. ${ }^{35}$

Kedua, tahap persuasi, di mana kader BSA dan kelompok sasaran program mampu mengajak beberapa tokoh masyarakat lain untuk mau terlibat dalam proses pembuatan SID. Ketiga, tahap pengambilan keputusan, yakni ditandai dengan telah ditetapkannya tim yang akan dilibatkan dalam pembuatan SID termasuk meminta bantuan beberapa mahasiswa dari Universitas Muhammadiyah Magelang yang kemudian perannya digantikan tim KKN PPM UGM JT-133. Selanjutnya, adalah tahap implementasi, yakni kala tim yang sudah ditetapkan dan dilatih kemudian mulai terjun melakukan survei dan pengambilan data untuk pembuatan SID. Terakhir tahap pemantapan, yakni kala tim yang terlibat dalam pembuatan SID mulai fokus untuk memastikan bahwa timeline kegiatan yang dibuat tidak akan melampaui jadwal atau justru bisa dipercepat pengerjaannya. ${ }^{36}$

Proses difusi inovasi yang dilakukan melalui bantuan teknis BSA dalam pembuatan sistem informasi desa telah menunjukan upaya di mana komunitas sosial mulai menilai dan membuka diri terhadap ide baru serta dihubungkan dengan situasi kehidupan masyarakat saat ini \& masa depan. BSA, aparat desa dan tokoh masyarakat telah menentukan untuk mencoba dan menerapkan inovasi dalam skala kecil untuk menentukan kegunaannya disebabkan sesuai dengan situasi internal komunitasnya. BSA bersama dengan kelompok sasarannya telah melakukan usaha pelaksanaan inovasi sosial dalam skala luas bagi internal komunitas di Kalibening, Dukun, Magelang. ${ }^{37}$

35 Farah Dwi Kania Nur Haida, "Difusi Dan Adopsi Inovasi Cyber Village Sebagai Fasilitas Internet Desa (Studi Deskriptif Kualitatif Difusi Inovasi Dan Adopsi Inovasi Cyber Village Pada Remaja Di Desa Campurejo, Kecamatan Tretep, Kabupaten Temanggung)", Universitas Sebelas Maret, 2017.

36 Haida, "Difusi dan Adopsi".

37 Rizal Ahmad, "Difusi Inovasi Dalam Meningkatkan
Proses pelaksanaan survei untuk basis data SID yang dilaksanakan oleh kader-kader BSA juga menunjukan bantuan teknis telah mendorong semakin meluasnya inovasi sosial. Survei mandiri yang dilakukan oleh kaderkader BSA itu sendiri telah menjadi bentuk inovasi sosial. Terdapat beberapa kriteria yang dapat mengkonfirmasi bahwa survei mandiri bagian dari bantuan teknis BSA telah menjadi sebuah inovasi sosial di Desa Kalibening. Pertama, pelaksanaan survei secara mandiri tersebut telah membawa gagasan/ide bahkan keterampilan baru yang dirasakan secara langsung oleh pihak-pihak yang dilibatkan dalam pembuatan SID di Kalibening. Kedua, pelaksanaan survei secara mandiri telah menjadi bagian dari upaya pemecahan masalah yang dihadapi oleh kelompok sasaran bersama dengan kader BSA. ${ }^{38}$

Ketiga, survei secara mandiri yang telah dilakukan oleh kader-kader BSA telah menunjukan keberanian untuk "menyimpang" dari kebiasaan lama yang semata memandang seolah-olah perempuan tidak dapat melibatkan diri dalam partisipasi pembangunan desa. Terakhir, proses yang dilakukan oleh kaderkader BSA bersama dengan kelompok sasaran menunjukan adanya proses inovasi sosial yang didorong oleh pihak internal dan eksternal komunitas masyarakat Desa Kalibening. ${ }^{39}$

Setelah dilakukan penyajian data, kaderkader BSA, kelompok sasaran dan tim KKN PPM UGM JT-133 kemudian dilibatkan dalam proses verifikasi data secara bersama-sama di bawah arahan dari trainer PP 'Aisyiyah. Kaderkader BSA, aparat desa, perwakilan warga dan tim KKN PPM UGM JT-133 dikumpulkan di Balai Desa Kalibening untuk mendapatkan arahan-arahan lanjutan dari trainer untuk

Partisipasi Masyarakat Akan Kelestarian Lingkungan,” Sosietas 6, No. 2 (2016): 1-17.

38 Sugiharini, "Difusi Inovasi Marketing Mix Melalui Kelompok Usaha Sektor Informal (Upaya Peningkatan Pemasaran Produk Sektor Informal)," Modernisasi 1, No. 3 (2005): 159-168.

39 Sugiharini, "Difusi Inovasi”, 159-168. 
melanjutkan proses pembuatan SID. Trainer dari PP 'Aisyiyah memberikan arahan mengenai pengolahan data dan pengarahan mengenai bentuk output SID. Trainer menjelaskan bahwa output akhir dari pengolahan data adalah untuk memetakan warga berdasarkan klasifikasi keluarga sejahtera.

PP 'Aisyiyah mendorong klasifikasi keluarga sejahtera bukan berdasarkan metodologi yang dipakai BKKBN, tetapi merancang secara mandiri pengelompokan warga yang akan tercermin dalam data SID. Setelah dilakukan pengelompokan data, nantinya akan ditindaklanjuti dengan proses ploting melalui GPS untuk memetakan warga berdasarkan kategori keluarga sejahtera. Penjelasan yang diberikan oleh trainer sebenarnya tidak mudah dipahami oleh kelompok sasaran, sehingga lebih mengantungkan pada tim KKN PPM UGM dalam pengolahan data.

Pihak PP 'Aisyiyah sayangnya kurang melibatkan partisipasi warga dalam menyusun indikator klasifikasi keluarga sejahtera. Pihak pendamping menjadi perumus tunggal dari metodologi kebijakan tanpa melibatkan kelompok sasaran. Akibatnya, basis metodologi kebijakan sebatas sebagai alat teknokrasi dibandingkan sebagai instrumen bersama di antara pemangku kepentingan. Warga diidentifikasi dengan indikator tertentu seolaholah hanya dilihat sebagai node, angka, dan grafis yang menjadi objek kebijakan dari pemerintah desa. Pihak pendamping menyusun kategori keluarga sejahtera dengan melihat indikator luas tanah, tingkat pendidikan, kemampuan menyekolahkan anak sampai jenjang tertentu dan tingkat pengeluaran keluarga. Warga yang diidentifikasi dalam klasifikasi keluarga sejahtera sebenarnya tidak mengerti kalau dirinya akan diintervensi melalui program kebijakan.

Pembuatan klasifikasi warga secara sepihak seolah memperlihatkan dipandang rendahnya pengetahuan warga desa. Pengetahuan ilmiah modern dari trainer yang ditunjang dengan basis material yang memadai dan prestise yang dimiliki telah menumbuhkan dan mendukung kepercayaan mereka tentang kehebatan ilmu pengetahuan mereka. Mereka meyakini bahwa dirinya lah yang paling penting. Warga desa sendiri melihat ilmu pengetahuan yang diperoleh dari sekolah dapat membawa seseorang pada kedudukan tinggi dan melepaskan diri dari kehidupan pedesaan menuju tatanan perkotaan yang dianggap menawarkan peluang dan kemajuan. Mereka para pembuat klasifikasi keluarga sejahtera mempunyai kebutuhan untuk memupuk kepercayaan bahwa pengetahuan dan kecakapan yang diperolehnya lebih unggul. Mereka beranggapan bahwa ilmu pengetahuan modern lebih canggih, maju, dan sah, sedangkan apa pun pengetahuan yang dimiliki orang desa dianggap tidak sistematis, tidak cermat, dan dangkal. ${ }^{40}$

Mereka tidak sadar jika pada hakikatnya kedudukannya tak lebih sebagai 'orang luar.' Menurut Chamber (1987), 'orang luar' adalah sebutan bagi orang-orang yang menaruh perhatian terhadap pembangunan desa, tetapi dirinya sendiri bukan warga desa apalagi miskin. 'Orang luar' tidak merasakan kemiskinan orang desa. Mereka tertarik dan terperangkap dalam 'kelompok inti' perkotaan yang mengembangkan dan menyebarkan ilmu serta kepandaian sendiri. Sementara, 'kelompok pinggiran' pedesaan tersisih dan terlupakan. Pengalaman langsung kebanyakan 'orang luar' tentang kehidupan di desa terbatas pada secara singkat dan tergesa-gesa. ${ }^{41}$

Trainer justru menggambarkan arah pembangunan desa dengan tatanan perkotaan. Trainer menanyakan kepada warga desa peserta pendampingan dengan bertanya pemahamannya mengenai berbagai aplikasi digital yang sudah digunakan di perkotaan. Warga tidak begitu

\footnotetext{
40 Robert Chambers, Pembangunan Desa Mulai Dari Belakang (Jakarta: LP3ES, 1987).

41 Chambers, Pembangunan Desa.
} 
mengerti mengenai berbagai aplikasi yang dimaksud serta situasi disrupsi teknologi yang coba digambarkan si trainer. Trainer menganggap bahwa situasi disrupsi teknologi itu perlu disiasati oleh warga desa yang bahkan tidak mengerti mengenai fenomena apakah itu.

Mahasiswa-mahasiswa dari tim KKN PPM UGM lah yang justru merespons berbagai penjelasan dari trainer mengenai situasi disrupsi teknologi yang menurutnya harus dihadapi warga desa. Trainer bahkan mengarahkan penggunaan drone dan digitalisasi dalam upaya pemetaan keluarga sejahtera dalam SID berdasarkan indikator yang dia buat. Padahal, saat melakukan pengecekan data saja kader BSA, perwakilan warga dan aparat masih kesulitan dalam mengoperasikan perangkat komputer. Mereka juga masih belum memiliki pemahaman yang memadai dalam membaca dan menafsirkan data.

Hubungan tidak asimetris muncul antara trainer dan kader BSA serta pemerintah desa. Hubungan tidak asimetris tidak hanya dalam hal kekuatan, tetapi juga dalam penguasaan pengetahuan dan komunikasi. Pendamping menganggap dirinya sebagai yang "tahu" dan "rasional", sedangkan pemangku lainnya diyakini sebagai yang "tidak mengerti." Ketidaktahuan pemangku kepentingan lain mengenai pengetahuan teknis modern sering perlu dipahami sebagai "protes secara diam." Mereka "yang merasa kalah" terpaksa harus menerima ide-ide aktor eksternal berdasarkan sains. Diamnya para peserta menjadi wujud lain dari resistensi dan mengarah pada tidak bertemunya kepentingan para aktor, di mana mereka sebenarnya berebut pengaruh. ${ }^{42}$

Trainer yang melakukan klasifikasi secara mandiri tanpa melalui partisipasi warga sebenarnya sedang melakukan depolitisasi. Di mana kepercayaan penuh pendamping akan

42 Christoph Antweiler, "Local Knowledge and Local Knowing. An Anthropological Analysis of Contested 'Cultural Products" in the Context of Development,"' Anthropos 93, No. 4/6 (1998): 469-94. pengetahuan ilmiah yang bersifat netral. ${ }^{43}$ Para pendamping diberi semacam ruang khusus yang lepas dari pentingnya masukan dari warga yang akan diintervensi oleh kebijakan. Kepercayaan ini sebenarnya dibangun dari epistemologi ilmu ekonomi yang sejak awal berfantasi bahwa ekonomi dan politik adalah dua ruang yang terpisah. Epistemologi ini menyatakan bahwa menyatukan keduanya akan menciptakan polusi yang tidak perlu dalam memahami proses-proses pembangunan dan kebutuhan yang terjadi di masyarakat. ${ }^{44}$

Peran trainer yang cenderung 'menggurui' kader BSA dan kelompok sasaran justru telah menyebabkan adanya persoalan baru yang bisa menghambat proses difusi dan inovasi sosial. Hambatan justru bisa muncul dalam proses bantuan teknis yang sedang dilakukan oleh kader BSA ini dapat ditinjau dari beberapa aspek. Pertama, aspek sosio-antro-psikologis, problem trainer yang memiliki latar belakang pribadi dari masyarakat perkotaan yang ingin 'mencangkokkan' pengetahuannya terhadap komunitas di Desa Kalibening justru menyebabkan proses difusi sosial yang akan dilakukan menjadi berbenturan. Tampaknya, trainer tidak memahami betul realitas sosial yang ada di Desa Kalibening, sehingga asal 'mencangkokkan' pengetahuannya tanpa melihat apakah sesuai dengan nilai, kondisi psikis, dan aspek antropologis di Kalibening. ${ }^{45}$

Kedua, aspek semantik, di mana trainer sebagai penyampai pesan inovasi sosial seharusnya mengerti 'bahasa sosial' yang bisa dipahami oleh kader BSA dan kelompok sasaran di Kalibening sebagai penerima informasi. Ketiga, aspek mekanis, yakni

43 Coen Husain Pontoh and Sulfikar Amir, "Sulfikar Amir: Klaim Teknokrat Bebas Kepentingan Adalah Mitos," IndoProgress, 2009, https://indoprogress. com/2009/12/sulfikar-amir-klaim-teknokrat-bebaskepentingan-adalah-mitos/.

44 Pontoh and Amir.

45 Azzura Yushara and Mahyuzar, "Difusi Inovasi Program Kreativitas Masyarakat Dalam Membangun Kampung Pariwisata Di Gampong Nusa Aceh Besar," Jurnal Ilmiah Mahasiswa FISIP Unsyiah 3, No. 2 (2018): $1-14$. 
berkaitan dengan media penyampaian yang dipilih oleh trainer yang berusaha mengangkat kemajuan berbagai aplikasi di perkotaan seolah-olah bisa menjadi analogi yang tepat dalam usaha menjelaskan pentingnya proses pembuatan SID di Kalibening. Terakhir, kondisi lingkungan berupa mayoritas warga yang dilibatkan dalam pembuatan SID sebenarnya tidak merasa membutuhkan berbagai pengetahuan tentang klasifikasi 'keluarga sejahtera' dan pemanfaatan aplikasi yang dibangun dari realitas masyarakat perkotaan. ${ }^{46}$

Tim KKN PPM UGM bersama pemangku kepentingan lain selanjutnya melakukan proses pengecekan data. Trainer mendorong tim KKN PPM UGM bersama pemerintah desa dan kader BSA untuk memastikan tidak ada data yang belum dicantumkan sekaligus cross check terhadap informasi yang dicantumkan. Pengecekan data bersama ini mendorong adanya perubahan informasi yang dicantumkan sebelumnya pada hasil survei BSA. Sayangnya, proses pengecekan data tidak didasarkan pada basis informasi yang memadai, tetapi terbatas pada penilaian subjektif dari kader BSA dan pemerintah desa. Kebenaran informasi yang dicantumkan menjadi patut dipertanyakan, padahal basis data yang ada akan digunakan untuk pengambilan kebijakan.

Data-data yang diambil oleh kader-kader BSA ternyata memiliki persoalan tersendiri dalam pengambilan informasinya, sehingga menyebabkan akurasi, kredibilitas, reliabilitas dan validitasnya menjadi bermasalah. Hambatan yang muncul dalam pengambilan data untuk SID disebabkan oleh kader-kader BSA kurang memiliki pemahaman dan skill memadai mengenai proses riset mandiri. Mereka kenyataannya tidak menemui langsung responden survei yang dituju, tetapi terkadang terbatas dengan bertemu kepala wilayah untuk memperkirakan data keluarga, kesehatan, kekayaan dan lain-lain yang dimiliki.

46 Yushara and Mahyuzar, "Difusi Inovasi".
Beberapa kader BSA juga ada yang terbatas bertemu dengan anak dari kepala keluarga responden yang dituju, sehingga validitas data menjadi patut dipertanyakan. Beberapa kader BSA juga ada yang hanya memperkirakan data responden berdasarkan pemahaman mereka secara awam mengenai tetangga mereka yang dijadikan responden survei. Hal ini menjadi cukup merepotkan bagi proses pengolahan data dan verfikasi bersama antara tim KKN PPM UGM dan kader BSA untuk memastikan kebenaran realitas sosial yang dibentuk.

Kader BSA dan aparat desa dibantu tim KKN PPM UGM secara mandiri melanjutkan proses pengecekan dan perbaikan data yang telah disajikan. Pengecekan data sayangnya tetap dilakukan sebatas dengan penilaian subjektif dari aparat desa dan kader yang terlibat dalam pengambilan data, dibandingkan langsung bertemu dengan responden. Partisipasi warga dalam perintisan SID ini pada dasarnya hanya dilakukan oleh segelintir orang yang tergabung dalam BSA. Mereka yang berada di luar BSA sebenarnya tidak mengerti mengenai proses perintisan SID di Desa Kalibening.

Setelah pengecekan data yang dilakukan dirasa cukup, BSA bersama trainer melanjutkan proses plotting rumah-rumah yang akan diklasifikan sebagai 'keluarga sejahtera.' BSA terus melaksanakan proses perintisan SID melalui pemetaan 'keluarga sejahtera.' Mereka memanfaatkan teknologi drone untuk melakukan plotting terhadap rumah warga berdasarkan klasifikasi keluarga sejahtera yang telah dibuat. BSA juga bekerjasama dengan Universitas Aisyiyah sempat mendiseminasikan upaya mereka dalam perintisan SID di Desa Kalibening, agar dapat ditiru oleh desa-desa lain di Kabupaten Sleman. Perintisan SID semakin meningkatkan kontribusi BSA dalam pembangunan dan penyelenggaraan pemerintahan Desa Kalibening. Akan tetapi, pelibatan kader BSA 
ini tidak dapat ditafsirkan sebagai partisipasi warga, melainkan pendampingan organisasi masyarakat sipil dalam pembangunan desa.

Pemetaan yang akan dilakukan diklaim sebagai 'proses partisipatif dengan melibatkan warga dalam plotting secara langsung tempat tinggalnya bersama dengan pendamping dari PP 'Aisyiyah. Akan tetapi, proses pemetaan ini sebenarnya tidak lebih dari proses administrasi publik yang dijalankan oleh pemerintah desa bersama dengan pendampingnya. Penggunaan peta modern menimbulkan masalah yang tidak diduga sebelumnya. Pembuatan peta modern mengharuskan kelompok-kelompok atau lembaga-lembaga dalam gerakan ini untuk tunduk pada nilai-nilai dan praktikpraktik kartograf. Padahal, teknologi tersebut semakin membuat masyarakat memiliki akses yang berkurang pada proses pengambilan keputusan sebagai tindak lanjut dari pemetaan sosial. Warga tidak memiliki pengetahuan yang sama dengan pihak pendamping dalam proses pemetaan, sehingga tidak memiliki political will dalam mempengaruhi agenda kebijakan dari klasifikasi keluarga sejahtera yang dipetakan. ${ }^{47}$

Proses eksklusi sosial dalam pelibatan BSA terjadi disebabkan tidak semua kalangan masyarakat dapat mengakses perintisan SID. Warga yang tidak tergabung dalam BSA, tidak memiliki kesempatan yang sama dalam proses perintisan SID. Sebagian warga justru memandang BSA sebagai salah satu elemen dari masyarakat saja yang tidak bisa dilepaskan dari formasi sosial di Desa Kalibening. BSA hanya mewakili satu formasi sosial yang ada, sehingga mengeksklusi warga lain yang berada di luar kelompoknya.

Tim KKN PPM UGM mencoba menjembatani pengolahan data dari hasil survei BSA untuk dimanfaatkan menjadi tampilan monografi di tingkat dusun yang

47 Albertus Hadi Pramono, "Perlawanan Atau Pendisiplinan? Sebuah Refleksi Kritis Atas Pemetaan Wilayah Adat," Wacana 33, No. 16 (2014): 207-42. dapat dimanfaatkan keseluruhan warga dalam melaksanakan pembangunan. Akan tetapi, penyusunan monografi yang disusun dari hasil survei BSA dibuat bukan tanpa hambatan. Data kasar monografi yang telah diserahkan kepada ketua RT setempat oleh tim KKN PPM UGM misalnya justru diminta kembali oleh oknum kader BSA. Kemudian, Ketua RT setempat mengkonfirmasi kejadian tersebut pada tim KKN PPM UGM. Tim KKN PPM UGM pun memberikan tampilan monografi final tanpa berkoordinasi dengan BSA di tingkat dusun. Kompromi antara aparat desa dan tim KKN PPM UGM ini terpaksa diambil untuk mencegah terulangnya kejadian sebelumnya. ${ }^{48}$

Tim KKN PPM UGM sesuai dengan kesepakatan yang dibangun dengan pemerintah desa mencoba memanfaatkan data dari hasil survei BSA untuk diolah menjadi output SID dalam bentuk lain. Tim KKN PPM UGM bersepakat dengan pemerintah desa untuk meluncurkan buku profil desa yang benar-benar mengambarkan inventarisasi potensi, fasilitas publik dan sumber daya pembangunan. Tim KKN PPM juga melakukan proses tracking data secara mandiri untuk membuat peta desa dan pengambilan gambar fasilitas publik yang ada. Tracking data dilakukan sebagai penambahan untuk memastikan bahwa informasi yang ada sesuai dengan realitas di lapangan. Tim KKN PPM UGM membuat pemetaan mengenai peta desa, peta sebaran potensi rawan bencana erupsi Gunung Merapi, dan peta dusun.

Setelah proses plotting data SID dirasa cukup, BSA bersama dengan trainer melakukan proses posting informasi desa di website yang telah disediakan. Pihak trainer telah melakukan proses pembuatan website desa dengan nama kalibening.id. Data-data yang telah disajikan kemudian ditampilkan dalam laman website kalibening.id. Kader-kader BSA yang telah dilatih mengenai pelaksanaan survei secara mandiri akan menjadi pihak yang membantu

48 Francisco, "The Documentation and Technical Assistance Project in Urban Schools.” 
proses pembaharuan terhadap data ke depannya. Kader dari BSA dan aparat desa yang telah dilatih juga mengoperasionalkan penggunaan website desa kalibening.id sebagai sumber partisipasi dalam pembangunan desa. Tampilan utama dalam website kalibening. id juga menampilkan informasi desa dengan kanal khusus dengan tajuk Desa Sehat. Hal ini mengikuti dengan visi donor BSA yang memang bergerak pada isu kesehatan masyarakat.

Sampai dengan tahap evaluasi kegiatan bantuan teknis, kader BSA akan menjadi pihak yang akan mengawal pelaksanaan SID. Bahkan, keberhasilan bantuan teknis BSA di Kalibening mendorong Universitas Aisyiyah Yogyakarta untuk mengundang Kepala Desa Kalibening untuk dijadikan narasumber dalam pelatihan pembuatan sistem informasi desa bagi kepala desa di Kabupaten Sleman dan Kabupaten Bantul, Provinsi Daerah Istimewa Yogyakarta.

Program bantuan teknis dengan model difusi dan inovasi sosial telah menyebabkan Desa Kalibening telah mampu mencapai target perubahan yang ingin dicapai antara kelompok sasaran dengan technical assistance. Setidaknya dari kasus perintisan SID di Desa Kalibening, Dukun, Magelang dapat dipahami ada beberapa klasifikasi aktor yang dapat dipetakan dalam mendukung proses difusi sistem informasi desa. Pertama, BSA dan jejaring organisasi masyarakat sipilnya yang telah menjadi inovator atau pelopor dalam upaya mengkomunikasikan dan mengawal penuh proses pembuatan SID di Desa Kalibening. Kedua, pemerintah desa terutama Kepala Desa Kalibening yang telah menjadi early adopter sebagai pihak yang memiliki akses dan pengaruh untuk mengkomunikasikan proses pembuatan SID, agar bisa diterima sistem sosial yang ada. Ketiga, tim KKN PPM UGM yang menjadi early majority yang melakukan penerimaan dan belakangan turut membantu proses pembuatan SID di Desa Kalibening bahkan turut memanfaatkannya untuk diolah menjadi inovasi sosial lain berupa buku profil desa dan monografi. ${ }^{49}$

\section{Kesimpulan}

Proses bantuan teknis yang dilakukan oleh BSA di Desa Kalibening telah sukses dalam mendorong difusi dan inovasi sosial. Proses difusi dan inovasi sosial yang berjalan di Kalibening, Dukun, Magelang setidaknya dapat dipahami telah melalui beberapa tahapan, yakni pertama, tahap pembelajaran, di mana pihak BSA dan PP 'Aisyiyah mulai memberikan pemahaman awal kepada kelompok sasaran tentang peran penting pembuatan sistem informasi desa sampai dengan pelatihan survei secara mandiri yang akan dijadikan basis data untuk SID. Kedua, tahap pengadopsian, yakni kala BSA dan kelompok sasaran telah menyepakati proses pembuatan SID, perancangan timeline kegiatan sampai dengan proses perintisan sistem informasi desa berlangsung dan menjadi program bersama. Ketiga, tahap pengembangan jaringan sosial, yakni kala BSA dan kelompok sasaran mampu membangun kerjasama dengan stakeholder lain seperti beberapa mahasiswa Universitas Muhammadiyah Magelang \& Tim KKN PPM UGM JT-133 yang kemudian membantu proses perintisan SID mulai dari proses penyajian sampai dengan pengecekan data. Bahkan dengan adanya pengembangan jaringan sosial, Tim KKN PPM UGM JT-133 dengan terlebih dahulu membangun kesepakatan dengan pihak BSA telah mengolah hasil survei untuk diolah menjadi inovasi sosial lain berupa buku profil desa dan monografi.

Peran BSA sebagai organisasi masyarakat sipil dalam menyebarluaskan proses pembuatan sistem informasi desa memainkan peranan yang kuat di Kalibening, tetapi langkah difusi sosial

49 Gede Sedana, "Pemberdayaan Masyarakat Berdasarkan Pada Kategori Adopter," DwijenAGRO 3, No. 1 (2012): $1-9$. 
yang dilakukan bukan tanpa persoalan. Proses difusi sosial sistem informasi desa setidaknya dapat dipahami memunculkan beberapa masalah yang bisa ditinjau dari beberapa aspek, yakni pertama, peran yang terlalu besar dari BSA kenyataannya justru menyebabkan adanya eksklusi sosial terhadap kemungkinan adanya peran serta dari kelompok warga lain di Desa Kalibening. Kedua, peran trainer yang cenderung 'menggurui' juga menunjukan bagaimana inovasi sosial berupa SID muncul secara 'top down' dari aktor supra desa berupa organisasi masyarakat sipil. Proses pembuatan SID yang 'top down' itu terlihat dari pembuatan klasifikasi secara sepihak mengenai makna atas 'keluarga sejahtera' bagi penduduk Desa Kalibening yang seolah-olah perlu diintervensi dengan bantuan-bantuan tertentu. Mekanisme top down itu juga semakin terlihat dengan cara trainer menjelaskan pentingnya keberadaan aplikasi di pedesaan dengan membandingkan keadaan di desa dan kota dengan seolah-olah menunjukan realitas di perkotaan lebih maju. Ketiga, trainer tidak sadar bahwa pihaknya juga tak lebih dari 'orang luar' yang sedang 'merasa paling tahu' dengan semata-mata sebenarnya memandang penduduk desa sebagai objek kebijakan. Usaha trainer untuk menggunakan GPS sebagai alat 'pendisiplin' dalam proses pemetaan 'keluarga sejahtera' sesuai data SID justru memperkuat bahwa penduduk desa hanya akan dilihat sebagai plot yang kemudian akan menjadi sasaran berbagai kebijakan.

Pelibatan kelompok warga lain dalam proses difusi dan inovasi sosial di Kalibening perlu ditingkatkan, agar masyarakat desa tidak semata menjadi objek dari intervensi yang dilakukan oleh aktor supra desa sekalipun berupa organisasi masyarakat sipil. Langkah pemerintah desa yang hingga saat ini masih rutin membangun jejaring dengan universitasuniversitas untuk mengirim mahasiswanya dalam kegiatan KKN dapat menjadi salah satu peluang peningkatan kapasitas dan partisipasi warga secara langsung dalam proses kebijakan. Pihak desa harus mampu mewadahi partisipasi internal warganya dan terus membangun jejaring sosial dengan aktor eksternal untuk turut memperkuat partisipasi dari dalam komunitas sosial itu sendiri. 


\section{DAFTAR PUSTAKA}

Ahmad, Rizal. "Difusi Inovasi Dalam Meningkatkan Partisipasi Masyarakat Akan Kelestarian Lingkungan.” Sosietas 6, No. 2 (2016).

Anonim. "Mitra MAMPU Berikan Dampak Pada Warga Aisyiyah." Suara Muhammadiyah, 2017. http://www. suaramuhammadiyah.id/2017/07/19/ mitra-mampu-berikan-dampak-padawarga-aisyiyah/.

- "Penggunaan Dana Desa Untuk Program Inovasi Desa." kemendesa.go.id, 2019. https://www.kemendesa.go.id/ view/detil/2910/penggunaan-dana-desauntuk-program-inovasi-desa.

Antweiler, Christoph. "Local Knowledge and Local Knowing. An Anthropological Analysis of Contested 'Cultural Products" in the Context of Development." Anthropos 93, No. 4/6 (1998).

Apriyansyah, Isnaini Maullidina, and Eko Priyo Purnomo. "Efektivitas Sistem Informasi Desa (SID) Dalam Pelayanan Publik Di Desa Dlingo, Kecamatan Dlingo, Kabupaten Bantul.” Jurnal Analisis Kebijakan Dan Pelayanan Publik 4, No. 1 (2018).

Asnamawati, Lina. "Strategi Percepatan Adopsi Dan Difusi Inovasi Dalam Pemanfaatan Mesin Tanam Padi Indojarwo Transplanter Di Kabupaten Bengkulu Utara Provinsi Bengkulu." In Prosiding Seminar Nasional FMIPA-UT 2015: Optimalisasi Peran Sains Dan Teknologi Menuju Kemandirian Bangsa, 2015.

Badri, Muhammad. "Pembangunan Pedesaan Berbasis Teknologi Informasi Dan Komunikasi (Studi Pada Gerakan Desa Membangun).” Risalah 27, No. 2 (2016).
Bappenas, and Australian Government. "M A M P U 2012 - 2020 Kemitraan AustraliaIndonesia Untuk Kesetaraan Gender Dan Pemberdayaan Perempuan.” mampu. or.id, 2019. http://www.mampu.or.id/ wp-content/uploads/2019/02/181008_ Mampu-Infokit-ID_FIN-lowerres.pdf.

Burke, Kevin, and Stuart Greene. "Participatory Action Research, Youth Voices, and Civic Engagement." Language Arts 92, No. 6 (2015).

Chambers, Robert. Pembangunan Desa Mulai Dari Belakang. Jakarta: LP3ES (Lembaga Penelitian, Pendidikan, dan Penerangan Ekonomi dan Sosial), 1987.

Clark, John. NGO Dan Pembangunan Demokrasi. Yogyakarta: Tiara Wacana, 1995.

Firdaus, Iqbal, and Riyanto. "Perancangan Website Pemerintah Desa Sebagai Media Penyebaran Informasi Bagi Masyarakat Dengan Metode Waterfall." Jurnal SAINSTECH Politeknik Indonusa 2, No. 6 (2016)

Francisco, Richard P. "The Documentation and Technical Assistance Project in Urban Schools." Theory Into Practice 18, No. 2 (1979).

Haida, Farah Dwi Kania Nur. "Difusi Dan Adopsi Inovasi Cyber Village Sebagai Fasilitas Internet Desa ( Studi Deskriptif Kualitatif Difusi Inovasi Dan Adopsi Inovasi Cyber Village Pada Remaja Di Desa Campurejo, Kecamatan Tretep, Kabupaten Temanggung)." Universitas Sebelas Maret, 2017.

Herpendi. "Sistem Informasi Desa Di Kecamatan Takisung." Jurnal Sains Dan Informatika 3, No. 2 (2017)

Hidayatulloh, Syarif, andCisde Mulyadi. "Sistem Pelayanan Administrasi Kependudukan Desa Candigatak Berbasis Web." Jurnal IT CIDA 1, No. 1 (2015): 42-55. 
Istana, and Zahri Nasuton. "Difusi Peningkatan Kapasitas Kelembagaan Pengelolaan Sumberdaya Perikanan (Studi Kasus Di Waduk Malahayu, Brebes Jawa Tengah)." Buletn Riset Sosek Kelautan Dan Perikanan 8, No. 1 (2013).

Kelen, Yoseph Pius Kurniawan, and Oktovianus Sikas. "Workshop Sistem Informasi Desa Dan Kawasan (SiDeKa) Desa Fatuana, Kecamatan Insana." Jati Emas (Jurnal Aplikasi Teknik Dan Pengabdian Masyarakat) 2, No. 2 (2018).

Le, Lan T., Bruno J. Anthony, Suzanne M. Bronheim, Courtney M. Holland, and Deborah F. Perry. "A Technical Assistance Model for Guiding Service and Systems Change." The Journal of Behavioral Health Services $\mathcal{E}$ Research, 2014.

Mansur, and Kasmawi. "Pengembangan Sistem Database Terpadu Berbasis Web Untuk Penyediaan Layanan Informasi Website Desa." Teknosi 3, No. 1 (2017).

Oktarina, Selly, and Sarwititi Sarwoprasodjo. "Strategi Komunikasi Politik Opinion LeaderDalamDifusiProgramPembangunan Dan Pengembangan Lembaga Lokal Di Pedesaan" MetaCommunication; Journal Of Communication Studies 3, no. 1 (2018).

Paryanta, Sutariyani, and DesiSusilowati. "Sistem Informasi Administrasi Kependudukan Berbasis Web Desa Sawahan.” IJSE Indonesian Journal on Software Engineering 3, No. 2 (2017).

Pontoh, Coen Husain, and Sulfikar Amir. "Sulfikar Amir: Klaim Teknokrat Bebas Kepentingan Adalah Mitos." IndoProgress, 2009.https://indoprogress.com/2009/12/ sulfikar-amir-klaim-teknokrat-bebaskepentingan-adalah-mitos/.

Pramono, Albertus Hadi. "Perlawanan Atau Pendisiplinan? Sebuah Refleksi Kritis Atas Pemetaan Wilayah Adat." Wacana 33, No. 16 (2014).
Rumaisa, Fitrah, and Robby. "Perancangan Sistem Informasi Aplikasi Untuk Pemerintahan Tingkat Desa Di Desa Dan Kelurahan.” researchgate, 2010. https://www. researchgate.net/publication/303881416_ Perancangan_Sistem_Informasi_Aplikasi_ untuk_Pemerintahan_tingkat_desa_di_ Desa_dan_Kelurahan.

Sedana, Gede. "Pemberdayaan Masyarakat Berdasarkan Pada Kategori Adopter." DwijenAGRO 3, No. 1 (2012).

Silaban, Julita. "Kemitraan Indonesia-Australia Melalui Program Mampu(Maju Perempuan Indonesia Untuk Penangulangan Kemiskinan) Untuk Pemberdayaan Perempuan" Repository Unikom, 2017. https://repository.unikom. ac.id/54461/.

Storm, William B., and Frank P. Sherwood. "Technical Assistance in Public Administration: The Domestic Role." Public Administration Review 14, No. 1 (1954).

Sudarsono, Bambang, and Arief Laila Nugraha. "Kajian Pendampingan Aparat Desa Dalam Kemandirian Pemetaan Infrastruktur Dan Potensi Desa (Studi Kasus: Desa Katonsari, Kabupaten Demak)." Elipsoida 1, No. 1 (2018).

Sugiharini. "Difusi Inovasi Marketing Mix Melalui Kelompok Usaha Sektor Informal (Upaya Peningkatan Pemasaran Produk Sektor Informal)." Modernisasi 1, No. 3 (2005).

Sulistyowati, Fadjarini, and MC. Candra Rusmala Dibyorin. "Partisipasi Warga Terhadap Sistem Informasi Desa” Jurnal Komunikasi ASPIKOM 2, No. 1 (2013).

Suranto. "Evaluasi Program Desa Mandiri Informasi Berbasis Aplikasi Android Sistem Informasi Desa (Sifordes)" INFORMASI: Kajian Ilmu Komunikasi 48, no. 1 (2018). 
Suryani, Sri Ok. "Motivasi Indonesia Menandatangani Subsidiary Arrangement Program Mampu Fase Ii Dengan Australia Tahun 2017.” JOM FISIP 5, No. 1 (2018).

Syafriani, Desi. "Purwarupa Sistem Informasi Geografis Bebrasis Web Untuk Pemerintah Desa (Studi Kasus Desa Karangsari Kabupaten Kulon Progo).” Momentum 19, No. 2 (2017).

Trohanis, Pascal Louis. "Technical Assistance: An Innovative Approach to Building New Partnerships in Continuing and Inservice Education." Educational Technology 20, No. 8 (1980).

Whyte, William F. "Advancing Scientific Knowledge Through Participatory Action Research.” Sociological Forum 4, No. 3 (1989).

Yushara, Azzura, and Mahyuzar. "Difusi Inovasi Program Kreativitas Masyarakat Dalam Membangun Kampung Pariwisata Di Gampong Nusa Aceh Besar.” Jurnal Ilmiah Mahasiswa FISIP Unsyiah 3, No. 2 (2018). 